\title{
Hubungan teknologi dan informasi yang terkait dengan kinerja dalam suatu perusahaan
}

\author{
Nama : Haqqan amien maziun \\ Email : haqqanamien1@gmail.com
}

Perubahan yang terjadi dalam sebuah proses kinerja suatu perusahaan mengharapkan kinerja yang lebih baik dengan alokasi suberdaya yang inovatif. Dalam sebuah perusahaan, perlu memahami keunggulan kompetitif agar perusahaan tersebut dapat memanajemen sebuah inovasi dengan adanya perubahan pada lingkungan yang lebih tinggi dikarnakan terdapat banyak perusahaan yang tidak dapat beradaptasi dengan lingkungan yang sekarang ini. Dengan demikian hubungan yang terjadi antara strategi dengan kinerja perusahaan dapat menimbulkan sebuah ekspektasi yang tidak sesuai dengan harapan dikarnakan sumberdaya yang tersedia berbeda. Terdapat juga teknologi dalam perusahaan yang dapat meningkatkan kinerja perusahaan hingga mencapai ekspektasi yang lebih baik. Dengan kemampuan teknologi perusahaan yang memadai, hal tersebut dapat meningkatkan ekspektasi suatu perusahaan dalam mengembangkan kemampuan dalam berbagai bidang pengembangan produk seperti pemasaran dan kolaborasi. Kinerja perusahaan juga berbasis dari strategi yang memiliki peluang terhadap perusahaan teknologi informasi. Hal tersebut juga telah menunjukkan bahwasannya ternologi informasi dapat mempengaruhi sebuah proses manajerial dalam mengambil sebuah keputusan. Dalam pengolahan data perusahaan, diwajibkan juga untuk meningkatkan kemampuan dalam hal teknologi informasi agar strategi dan kinerja suatu perusahaan dapat terarah dan berjalan sesuai dengan harapan yang baik. Dengan demikian juga, manajer dan pembuat kebijakan mau memberikan perhatian terhadap kemampuan teknologi informasi yang dapat membuat peruahaan memiliki kemampuan dalam daya saing yang kuat dan dapat bertahan dilingkungannya. 